\title{
Studies on the Utilization of Nitrate by Micrococcus denitrificans
}

\author{
By JOAN P. CHANG AND J. G. MORRIS* \\ Microbiology Unit, Department of Biochemistry, University of Oxford
}

(Received 12 January 1962)

\begin{abstract}
SUMMARY
Micrococcus denitrificans is capable of carrying out assimilatory and dissimilatory nitrate reduction, though only the assimilatory process occurs under both aerobic and anaerobic conditions. Aeration affects the dissimilatory activity (reduction of nitrate to nitrogen) of a growing culture in at least three ways: $(a)$ it prevents the adaptive formation of the system, (b) it partially represses any further synthesis if the system is already present, and $(c)$ it inhibits the activity of the preformed system completely. To some extent these effects of oxygen are reflected in the control which it exerts upon the organism's content of nitrate reductase (the enzyme responsible for the initial reduction of nitrate to nitrite) and upon its activity during growth.

Ammonium ions partially inhibit the transformation of nitrate into cell nitrogen but have no detectable effect on the nitrate reductase activity of crude extracts of this organism.
\end{abstract}

\section{INTRODUCTION}

Several attempts have been made to categorize the various routes whereby nitrate ions may be reduced by micro-organisms. Some have been concerned with the nature of the actual components of the reaction sequences, e.g. the criterion of participation of cytochromes suggested by Taniguchi, Sato \& Egami (1956). However, until the actual metabolic routes have been more fully characterized it would appear to be advisable to use a classification based on physiological function. Verhoeven (1956) thus distinguished three types of nitrate reduction: (1) Assimilatory; where the nitrate is utilized by the growing organism solely as a source of nitrogen. (2) True dissimilatory; where the nitrate acts as terminal hydrogen acceptor in anaerobic growth of the organism. (3) Incidental dissimilatory; in which nitrate is used as a non-essential hydrogen acceptor with nitrite as the usual product.

That any real distinction may be drawn between 'true' and 'incidental' dissimilation is queried by some, who would group both types under the one heading of 'nitrate dissimilation or respiration' (Fewson \& Nicholas, 1961 a).

Oxygen is known to prevent the development of the true nitrate dissimilatory pathway with its attendant nitrogen production, in several bacteria, e.g. Pseudomonas denitrificans (Sacks \& Barker, 1949), P. stutzeri (Allen \& van Niel, 1952), Micrococcus denitrificans (Kluyver \& Verhoeven, 1954), and P. aeruginosa (Collins,

* Present address : Department of Biochemistry, University of Leicester. 
1955). An inhibitory effect of oxygen on nitrate reduction by washed suspensions of organisms previously adapted to nitrate utilization has also been observed (Sacks \& Barker, 1949; Skerman \& MacRae, 1957 a, b). On the other hand, there have been reports of loss of nitrate in the form of gaseous nitrogenous products from aerobically growing cultures (Meiklejohn, 1940; Marshall, Dishburger, MacVicar \& Hallmark, 1953; Verhoeven, 1956). This seeming contradiction of results has been largely resolved by the studies of Skerman and his colleagues (Skerman, Lack \& Millis, 1951; Skerman \& MacRae, 1957 $a, b$; 1961) which related the prevention of nitrate dissimilation to the actual oxygen tension in solution.

With nitrate as sole source of nitrogen for growth, Verhoeven (1956) obtained evidence for assimilatory reduction of nitrate during aerobic growth of Micrococcus denitrificans, though in anaerobic growth on a medium containing an alternative source of nitrogen all the nitrate consumed was accounted for as nitrogen or nitrous oxide.

We found that assimilatory reduction of nitrate could be effected by Micrococcus denitrificans during anaerobic, as readily as during aerobic growth, i.e. for this organism nitrate is a sufficient if not optimal source of nitrogen for growth. The effect of oxygen on the energy-yielding dissimilatory pathway and of ammonium ions on the assimilatory pathway has been examined.

\section{METHODS}

Organism. The strain of Micrococcus denitrificans obtained from Dr June Lascelles had been kindly supplied by $\mathrm{Dr}$ W. Verhoeven. It was maintained on peptone nitrate slopes containing the following (g./litre): peptone (Evans Medical Supplies Ltd., Liverpool), $10 ; \mathrm{K}_{2} \mathrm{HPO}_{4}, 1 ; \mathrm{MgSO}_{4} .7 \mathrm{H}_{2} \mathrm{O}, 0.5$; glycerol, 10; agar, 20; the $\mathrm{pH}$ was adjusted to $7 \cdot 0$. Inocula for liquid media were taken from such slopes after 20 to $30 \mathrm{hr}$. incubation at $30^{\circ}$.

Medium. The defined liquid medium consisted of the following (g./litre): sodium succinate, $6 \mathrm{H}_{2} \mathrm{O}, 13.5 ; \mathrm{K}_{2} \mathrm{HPO}_{4}, 6 ; \mathrm{KH}_{2} \mathrm{PO}_{4}, 4 ; \mathrm{MgSO}_{4} .7 \mathrm{H}_{2} \mathrm{O}, 0.2 ; \mathrm{CaCl}_{2}, 0.04$; sodium molybdate, $0 \cdot 15 ; \mathrm{MnSO}_{4} .4 \mathrm{H}_{2} \mathrm{O}, 0.001$; and an iron citrate solution, $5 \mathrm{ml}$. (containing in g./litre, $\mathrm{FeSO}_{4} \cdot 7 \mathrm{H}_{2} \mathrm{O}, 1 \cdot 1$; citric acid. $\mathrm{H}_{2} \mathrm{O}, \mathbf{1 \cdot 0 5}$ ) with $\mathrm{NH}_{4} \mathrm{Cl}, \mathbf{1} \cdot 6$; and $\mathrm{KNO}_{3}, 10 \cdot 1$ being added as required.

Growth conditions and preparation of suspensions. Anaerobic cultures were incubated in glass-stoppered bottles completely filled with medium. Aerobic cultures were incubated either in $100 \mathrm{ml}$. volumes per 11 . Erlenmeyer flask or in $200 \mathrm{ml}$. volumes per 2 l. Erlenmeyer flask, shaken at 160 to $200 \mathrm{rev} . / \mathrm{min}$. in a gyrotary shaker (New Brunswick Scientific Co., New Brunswick, N.J., U.S.A.). All incubation was at $30^{\circ}$. After harvesting in the exponential phase of growth, all cells were washed in a $0.1 \mathrm{M}$-phosphate salts buffer, $\mathrm{pH} \mathrm{6.8} \mathrm{(0.1} \mathrm{M-phosphate} \mathrm{pH} 6.8$ containing the same concentrations of $\mathrm{MgSO}_{4}, \mathrm{CaCl}_{2}, \mathrm{MnSO}_{4}$, sodium molybdate and iron citrate as the growth medium).

In those growth experiments where a comparatively large inoculum of adapted organisms was required, cultures were harvested during exponential growth and stored overnight at $2^{\circ}$ as a thick suspension in $0.1 \mathrm{M}$-phosphate salts buffer. On the following day these organisms were used to inoculate large quantities of fresh medium previously warmed to $30^{\circ}$; growth then began almost immediately.

Assessment of groweth. The extent of growth was measured with an EEL photo- 
electric colorimeter (Evans Electroselenium Ltd., Halstead, Essex) with a neutral density filter and $15.8 \mathrm{~mm}$. sample tubes; the uninoculated medium was used to give zero setting. The relation between 'EEL reading' and dry weight was determined and found linear up to a reading of 35-40 with a progressive departure from linearity thereafter. For the linear part of the curve 10 'EEL units' was equivalent to $\mathbf{0 . 4} \mathrm{mg}$. dry weight.

Preparation of cell-free extracts. Exponentially growing organisms were harvested,

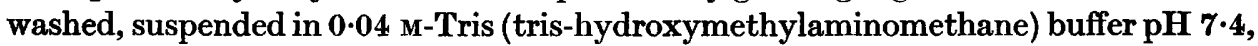
and disrupted by ultrasonic vibration for $5 \mathrm{~min}$. at $25 \mathrm{kc}$. $/ \mathrm{sec}$. in a Mullard ultrasonic generator type E 7590B (Mullard Ltd., London, W.C. 1). Unbroken cells and debris were removed by centrifuging at $17,400 \mathrm{~g}$ for $10 \mathrm{~min}$. at $0^{\circ}$.

Enzyme assays. Nitrate dissimilatory activity (referred to as nitratase) was estimated by manometric measurement of $\mathrm{N}_{2}$ evolution from nitrate. The main compartment of each manometer vessel contained washed organisms (2.7-3.6 mg. dry wt./ml.); $140 \mu$ mole phosphate salts buffer, $\mathrm{pH} 6.8$; $600 \mu$ mole sodium succinate; water to $2.5 \mathrm{ml}$. The centre well contained $0.2 \mathrm{ml} .20 \%(\mathrm{w} / \mathrm{v}) \mathrm{KOH}$. The reaction was started by addition of $100 \mu \mathrm{mole} \mathrm{KNO}_{3}$ from the side arm. Incubation was at $30^{\circ}$ in an atmosphere of oxygen-free nitrogen (British Oxygen Gases Ltd.).

Nitrate reductase activity was assayed in cell-free extracts. The reaction mixture consisted of $100 \mu$ mole Tris buffer, $\mathrm{pH} 7.9$; $100 \mu$ mole sodium succinate; $0.1 \mathrm{ml}$. crude extract (about $1 \mathrm{mg}$. protein); water to $1.9 \mathrm{ml}$. The reaction was started by the addition of $20 \mu$ mole $\mathrm{NaNO}_{3}$. After $15 \mathrm{~min}$. incubation at $30^{\circ}$ protein was precipitated with $0.1 \mathrm{ml}$. of $2 \mathrm{M}$ zinc acetate followed by $1.9 \mathrm{ml} .95 \%(\mathrm{v} / \mathrm{v})$ ethanol (Fewson \& Nicholas, $1961 b$ ). The precipitate was removed by centrifuging and samples of the supernatant assayed for nitrite.

Succinic dehydrogenase activity of crude extracts was determined spectrophotometrically using 2:6-dichlorophenol-indophenol and phenazine methosulphate (Redfearn \& Dixon, 1961).

Protein estimation. This was performed by the method of Lowry, Rosebrough, Farr \& Randall (1951) using crystalline bovine plasma albumin (Armour Laboratories Hampden Park, Eastbourne, Sussex) as standard.

Chemical estimations. Nitrite was determined colorimetrically by a method modified from that of Rider \& Mellon (1946) as described by Lascelles (1956).

Nitrate was assayed as nitrite after chemical reduction by a method developed by Dr D. J. D. Nicholas (personal communication to Dr June Lascelles). Samples containing up to $2.5 \mu$ mole of nitrate were diluted to $2.5 \mathrm{ml}$. with distilled water, $2.5 \mathrm{ml}$. of $2 \mathrm{~N}-\mathrm{NaOH}$ was added to bring the $\mathrm{pH}$ to between 11 and $11 \cdot 6$, and the mixtures shaken vigorously for $5 \mathrm{~min}$. with about $0.05 \mathrm{~g}$. zinc powder in stoppered test tubes held in a microid shaker. After immediate centrifuging the nitrite content of the supernatant was determined colorimetrically.

Ammonia was estimated by the phenate-hypochlorite method (Conway, 1950), and cell nitrogen similarly after conversion to ammonium sulphate by the Kjeldahl method (Conway, 1950). 


\section{RESULTS}

Existence of both assimilatory and dissimilatory routes of nitrate utilization

Micrococcus denitrificans grew well with nitrate as sole source of nitrogen under both aerobic and anaerobic conditions (Fig. 1b). The lag period was shorter in the presence of ammonium ions. In a medium containing both nitrate and ammonium ions the lag period was longer and the rate of growth slower in anaerobic than in aerobic conditions (Fig. $1 a$ ).

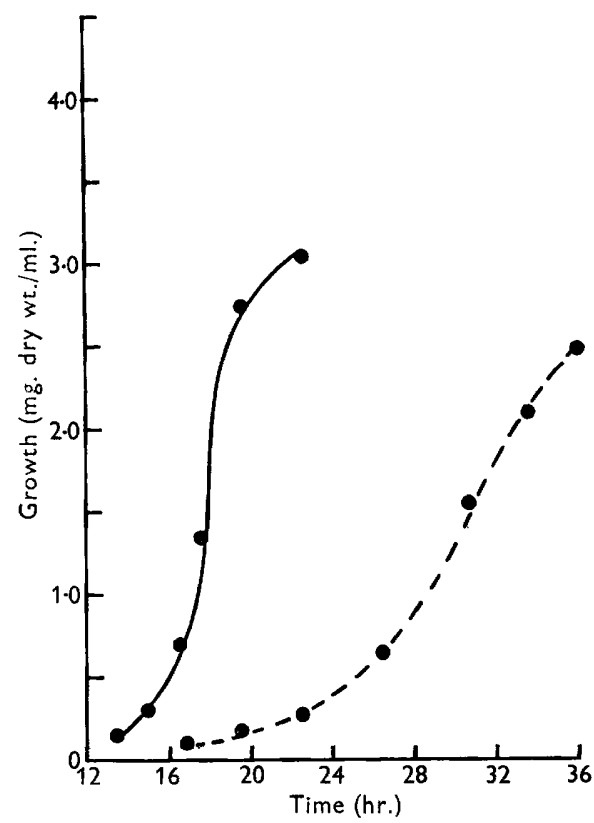

Fig. $1 a$

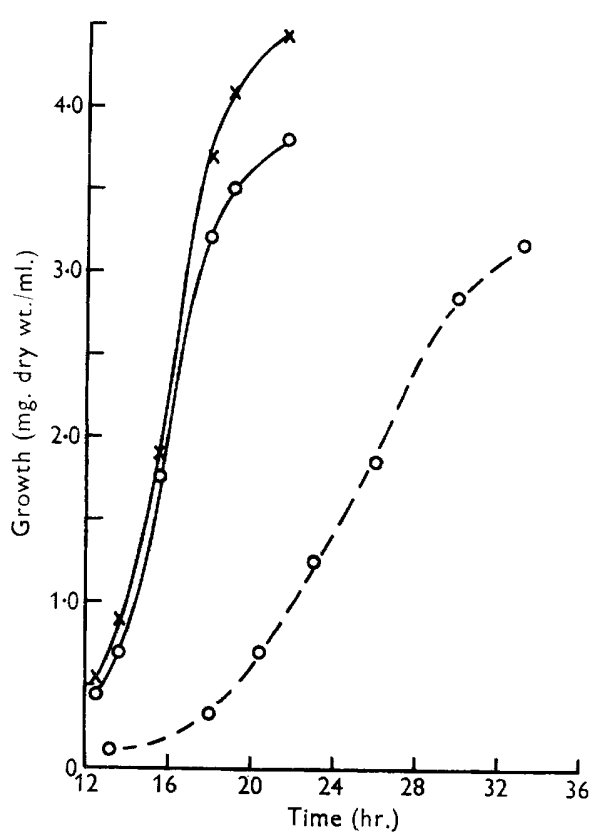

Fig. $1 b$

Fig. 1a. Growth of Micrococcus denitrificans on nitrate as sole source of nitrogen. -, aerobic and - - - anaerobic.

Fig. 1 b. Growth of Micrococcus denitrificans on media containing ammonium ions. -, aerobic; - - , anaerobic; $x$, ammonium chloride only, 0 , nitrate plus ammonium ions.

\section{The effect of aeration on the formation of enzymes concerned with nitrate utilization}

Two enzyme systems were studied. (1) Nitratase-the sequence of enzymes effecting the reduction of nitrate to nitrogen gas. (2) Nitrate reductase-the enzyme system reducing nitrate to nitrite.

Nitratase. Organisms grown aerobically in the presence of nitrate could not reduce nitrate to nitrogen in contrast to those grown anaerobically with nitrate as hydrogen acceptor, which showed considerable nitratase activity (Table 1).

The effect of aeration on nitratase synthesis was examined in growing cultures. Part of a culture growing anaerobically on nitrate plus ammonia was transferred early in exponential growth to aerobic conditions, the remainder being allowed to continue anaerobically. Nitratase activity and growth were measured at intervals. 


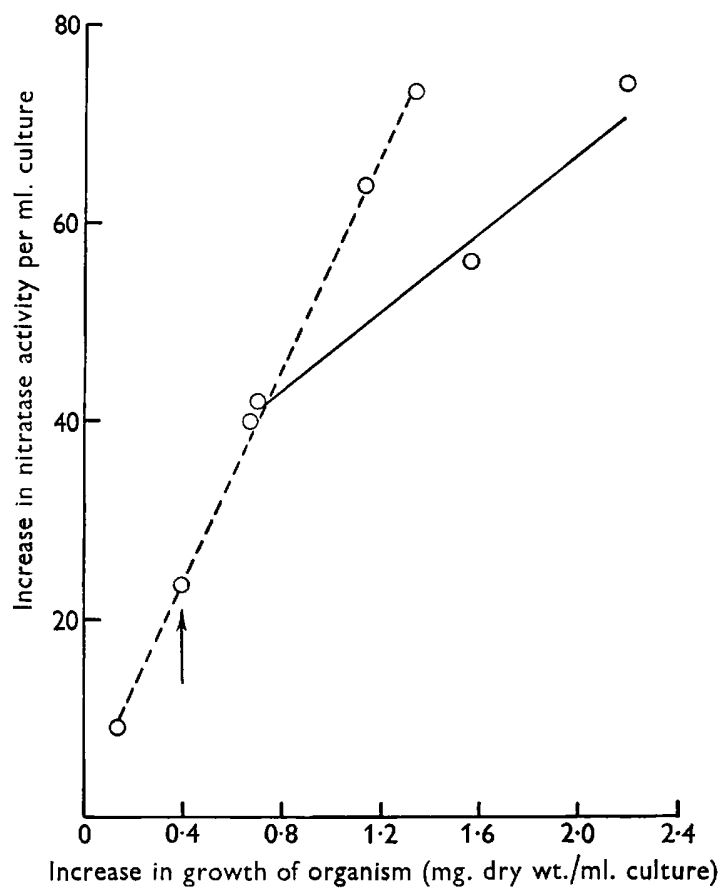

Fig. 2. The efiect of aeration on the synthesis of nitratase in cultures of Micrococcus denitrificans growing on nitrate plus ammonium ions. Nitratase activity was measured as $\mu \mathrm{I} . \mathrm{N}_{2}$ produced/mg./hr. - , aerobic; - - -, anaerobic.

Table 1. Nitratase activity of washed suspensions of Micrococcus denitrificans

Nitratase activity was calculated from nitrogen evolution during the first $30 \mathrm{~min}$. of assay.

$\begin{array}{ccc}\text { Nitrogen source in medium } & \text { Growth conditions } & \begin{array}{c}\text { Nitratase } \\ \text { activity } \\ \mu \mathbf{l} . \mathbf{N}_{2} \\ \text { formed/mg. } \\ \text { dry wt./hr. }\end{array} \\ \text { Ammonia } & \text { Aerobic } & 0 \\ \text { Ammonia plus nitrate } & \text { Aerobic } & 0 \\ \text { Ammonia plus nitrate } & \text { Anaerobic } & \mathbf{5 4}\end{array}$

The results show that there was partial repression of nitratase synthesis after about $1.5 \mathrm{hr}$. exposure to air introduced at $\uparrow$ in Fig. 2.

Nitrate reductase. Crude sonic extracts were tested for nitrate reductase activity under conditions where they showed no detectable nitrite reductase activity (Methods). Preliminary experiments showed that at the $\mathrm{pH}$ optimum of $\mathbf{7 \cdot 9}$, activity was linear with both protein concentration (over the range $0 \cdot 15-1.5 \mathrm{mg}$. protein per $\mathrm{ml}$.) and with time (up to $25 \mathrm{~min}$.). Using the standard assay procedure described, nitrate reductase levels were measured in extracts of organisms grown under conditions in which the supply of oxygen and of nitrate was varied (Table 2).

Extracts of aerobically grown organisms showed no nitrate reductase activity if nitrate had been omitted from their growth medium and only low activity after 
growth in its presence. High activity was found only in extracts of anaerobically grown organisms. These results could not be attributed to destruction or irreversible inhibition of the enzyme by oxygen since organisms harvested during exponential growth on ammonium plus nitrate ions under anaerobic conditions showed no loss of activity after $60 \mathrm{~min}$. aeration. It was concluded therefore that oxygen at atmospheric pressure greatly diminishes the synthesis of nitrate reductase.

Since succinate was used as hydrogen donor in the nitrate reductase assay, succinic dehydrogenase activity was measured in each extract. Though there was some variation in the activity of this enzyme under the various conditions of growth, these differences were not of the same order of magnitude as those found in nitrate reductase activity, and in all cases the rate of succinate oxidation was considerably greater than the rate of nitrate reduction (Table 2).

Table 2. Nitrate reductase and succinic dehydrogenase levels in cell-free extracts of Micrococcus denitrificans

Nitrate reductase activity expressed as $\mu$ mole nitrite formed/mg. protein $/ 15 \mathrm{~min}$. Succinic dehydrogenase activity expressed as $\mu$ mole succinate reduced/mg. protein/ $15 \mathrm{~min}$.

$\begin{array}{llcc}\begin{array}{c}\text { Nitrogen source in } \\ \text { growth medium }\end{array} & \begin{array}{c}\text { Growth } \\ \text { conditions }\end{array} & \begin{array}{c}\text { Nitrate } \\ \text { reductase } \\ \text { activity }\end{array} & \begin{array}{c}\text { Succinic } \\ \text { dehydro- } \\ \text { genase } \\ \text { activity }\end{array} \\ \text { Ammonia } & \text { Aerobic } & 0 & \mathbf{9 \cdot 8} \\ \text { Ammonia plus nitrate } & \text { Aerobic } & \mathbf{0 \cdot 0 3} & \mathbf{8 \cdot 6} \\ \text { Nitrate } & \text { Aerobic } & \mathbf{0 \cdot 0 1} & \mathbf{6 \cdot 1} \\ \text { Ammonia plus nitrate } & \text { Anaerobic } & 1.27 & \mathbf{2 7 \cdot 6} \\ \text { Nitrate } & \text { Anaerobic } & \mathbf{1 . 9 6} & \mathbf{2 2 \cdot 4}\end{array}$

Table 3. The effect of aeration on nitrate utilization by growing cultures of Micrococcus denitrificans

\begin{abstract}
A culture growing anaerobically on nitrate as sole $\mathbf{N}$-source was divided into two portions. One was allowed to continue anaerobically, the other was transferred to aerobic conditions and incubation of both was continued for $\mathbf{9 \cdot 2 5} \mathbf{h r}$. The values listed represent changes occurring from the point of transfer, $(-)$ indicating disappearance and $(+)$ increase in medium component or in organisms. The concentration of all nitrogenous compounds is expressed as $\mu$ mole $\mathbf{N}$ per $\mathrm{ml}$.
\end{abstract}

\begin{tabular}{lcc} 
& \multicolumn{2}{c}{ Growth conditions } \\
\cline { 2 - 3 } Anaerobic & Aerobic \\
Growth (mg. dry wt./ml.) & +1.88 & $+\mathbf{2 . 7 4}$ \\
Nitrate utilized & $-\mathbf{4 1 . 0}$ & $-\mathbf{1 9 \cdot 3}$ \\
Nitrite formed & $\mathbf{+ 2 6 . 6}$ & $+\mathbf{6 . 9}$ \\
Ammonia formed & 0 & 0 \\
Cell nitrogen formed & $+\mathbf{3 . 0}$ & $+\mathbf{1 2 . 8}$ \\
Nitrogen balance & $\mathbf{- 1 1 . 4}$ & $+\mathbf{0 . 4}$
\end{tabular}

The effect of aeration on nitrate utilization by growing cultures

Aeration partially represses further nitratase synthesis in cultures that had previously been growing anaerobically (Fig. 2). However, it was not known whether the residual enzyme (of considerable activity if assayed under favourable anaerobic conditions), was at all functional under the adverse aerobic conditions. This was examined in balance experiments with growing cultures when the con- 
centrations of nitrate, nitrite and ammonia in the medium, together with cell nitrogen content, were measured. Imbalance between supply and recovery of nitrogenous compounds was ascribed to loss of gaseous products, particularly of nitrogen. In these studies Micrococcus denitrificans was incubated anaerobically on nitrate as sole nitrogen source and early in the exponential phase of growth a portion was transferred to aerobic conditions. Both cultures were then sampled at intervals, the final balance only being given in Table 3. Anaerobically, as was to be expected, there was considerable loss of nitrogen. Aerobically, the nitrate utilized was completely accounted for as nitrite and cell nitrogen. Thus nitratase is completely inactive under aerobic conditions of growth, which in turn suggests that one at least of the enzymes reducing nitrite to nitrogen is more susceptible to inhibition and possibly repression than is nitrate reductase itself.

The effect of ammonium ions on the aerobic utilization of nitrate by growing cultures

It was thought that ammonium ions which are at the same oxidation level as cell nitrogen and are a better source than nitrate or nitrogen for growth, might repress or inhibit (or both) nitrate assimilation. Ammonium chloride (0.65 g./1.) was added during exponential, aerobic growth of organisms provided with nitrate as sole nitrogen source. Both nitrate uptake and nitrite formation were inhibited (Table 4).

Table 4. The effect of ammonium ions on the aerobic utilization of nitrate by growing cultures of Micrococcus denitrificans

A culture growing aerobically on nitrate as sole $\mathrm{N}$-source was divided into two portions. $\mathrm{NH}_{4} \mathrm{Cl}$ (650 mg./1.) was added to one, no addition was made to the other and incubation of both was continued for $4 \mathrm{hr}$. The values listed represent changes occurring from the point of addition of $\mathrm{NH}_{4} \mathrm{Cl}$, the concentration of all nitrogenous compounds being expressed as $\mu$ mole $\mathbf{N}$ per $\mathbf{m l}$.

$\begin{array}{lcc}\overbrace{}^{\text {Nitrate }} & \begin{array}{c}\text { Nitrate } \\ \text { plus } \mathrm{NH}_{4} \mathrm{Cl}\end{array} \\ \text { Growth (mg. dry wt./ml.) } & +1.0 & +1.21 \\ \text { Nitrate utilized } & -7.8 & -4.4 \\ \text { Ammonia utilized } & 0 & -6.9 \\ \text { Nitrite formed } & +1.4 & 0 \\ \text { Cell nitrogen formed } & +5.0 & +7 \cdot 0 \\ \text { Nitrogen balance } & -1.4 & -4.3\end{array}$

The overall nitrogen imbalance in this experiment could not be due to loss of nitrogen as gas since similarly grown organisms possessed no nitratase activity. In the early stages of aerobic growth on nitrate as sole nitrogen source only part of the nitrate removed from the medium could be recovered while at the end of the exponential phase recovery was complete (Table 5). Nitrate present in the cells but not converted to cell nitrogen would not be quantitatively converted to ammonia by Kjeldahl digestion due to loss as nitric acid vapour (Vogel, 1951). Consequently the early apparent loss of nitrogen may be due to nitrate being taken into the organisms during exponential growth at a rate greater than that at which it is reduced, i.e. being accumulated within the cells. 
The effect of ammonium ions on nitrate reductase activity

Since nitrite formation was abolished by the addition of ammonia (Table 4), it was thought possible that ammonium ions might inhibit nitrate reductase activity. However, ammonium chloride $(30 \mathrm{~mm})$ had no adverse effect on nitrate reductase activity in extracts of organisms grown aerobically on nitrate as sole source of nitrogen.

Table 5. Recovery of nitrogen during aerobic growth of Micrococcus denitrificans on nitrate as sole source of nitrogen

\begin{tabular}{cc} 
Growth & $\begin{array}{c}\text { Nitrogen recovered as nitrite, } \\
\text { ammonia and cell nitrogen }\end{array}$ \\
\cline { 2 - 2 } (mg. dry wt./ml.) & $\begin{array}{c}\text { Decrease in nitrate nitrogen } \\
\text { in medium }\end{array}$ \\
$\mathbf{0 . 6 6}$ & $\mathbf{7 7}$ \\
$1 \cdot 16$ & 62 \\
$\mathbf{2 \cdot 2 6}$ & $\mathbf{6 2}$ \\
$\mathbf{3 \cdot 5 3} *$ & 97 \\
& \\
& End of exponential growth.
\end{tabular}

\section{DISCUSSION}

Cultures of Micrococcus denitrificans grew more rapidly aerobically than anaerobically in a medium containing both nitrate and ammonium ions (Fig. 1b). This could be due to electron transfer to oxygen being more efficient than comparable transfer to nitrate as a source of high energy phosphate. Phosphorylation linked to incidental nitrate reduction has been reported in Escherichia coli (Takahashi, Taniguchi \& Egami, 1956) and to true dissimilation in Pseudomonas denitrificans (Ohnishi \& Mori, 1960). However, a comparative study of the energetic yields of all these processes in the same organism has yet to be carried out.

In the control of nitrate dissimilation by oxygen in this organism inhibition of nitratase activity is of primary importance in the short term (Table 3 ). The function of repression of the development of nitratase by oxygen in the long term is difficult to assess since the rate of synthesis of nitratase in organisms previously grown anaerobically is only partially reduced by aeration (Fig. 2), while cultures grown wholly aerobically under apparently the same oxygen tension contain no detectable nitratase, even when the assay for its activity is performed anaerobically (Table 1).

Ammonium ions apparently inhibit nitrate reduction and its conversion into cel nitrogen. From the results obtained (Table 4), it is evident that the figures for aerobic nitrate disappearance agree well with those for concurrent increase in cell nitrogen. In the presence of ammonium ions, even if all the nitrate utilized aerobically were converted into cell nitrogen, it would be insufficient to account for the total increase in cell nitrogen. Using $\mathrm{N}^{15} \mathrm{H}_{4}$ and $\mathrm{N}^{15} \mathrm{O}_{3}$, Marshall et al. (1953) have shown that ammonium ions largely, if not completely, prevent the incorporation of nitrate into cell protein in Pseudomonas fluorescens and $\boldsymbol{P}$. denitrificans. This would seem also to be the situation in Micrococcus denitrificans.

An attempt was made to demonstrate a correlation between hydroxylamine 
metabolism by washed suspensions of Micrococcus denitrificans, and the ability of these organisms to assimilate nitrate, with the prospect that ammonium ions might act in an aerobically growing culture by feed-back inhibition either of an enzyme producing hydroxylamine or of a specific hydroxylamine reductase. In fact, there was no significant difference between organisms grown aerobically on nitrate and those grown on ammonium ions as sole source of nitrogen with respect to hydroxylamine utilization. It is, of course, possible that a basal hydroxylamine reductase activity associated with some other function, such as was reported in the case of sulphite reduction by Mager (1960), could mask a specific 'assimilatory' hydroxylamine reductase activity.

We should like to thank Professor D. D. Woods, F.R.S. and Dr June Lascelles for their advice and encouragement. One of us (J.P.C.) is indebted to the Medical Research Council for Training in Research; one of us (J.G.M.) was a Guinness Research Fellow at the time of this work.

\section{REFERENCES}

Allen, M. B. \& van Niel, C. B. (1952). Experiments on bacterial denitrification. J. Bact. 64, 397.

Collins, F. M. (1955). Effect of aeration on the formation of nitrate-reducing enzymes by Pseudomonas aeruginosa. Nature, Lond. 175, 193.

Conway, E. J. (1950). Microdiffusion Analysis and Volumetric Error, 3rd ed. London: Lockwood and Son.

Fewson, C. A. \& Nicholas, D. J. D. (1961 a). Utilization of nitrate by micro-organisms. Nature, Lond. 190, 3.

Fewson, C. A. \& Nicholas, D. J. D. (1961b). Nitrate reductase from Pseudomonas aeruginosa. Biochem. biophys. Acta, 49, 335.

KluYver, A. J. \& Verhoeven, W. (1954). Studies on true dissimilatory nitrate reduction. IV. On adaptation in Micrococcus denitrificans. Antonie van Leeurvenhoek J. Serol. Microbiol. 20, 337.

LASCELLES, J. (1956). An assay of iron protoporphyrin based on the reduction of nitrate by a variant strain of Staphylococcus aureus; synthesis of iron protoporphyrin by suspensions of Rhodopseudomonas spheroides. J. gen. Microbiol. 15, 404.

Lowry, D. H., Rosebrough, N. J., Farr, A. L. \& Randall, R. J. (1951). Protein estimations with the folin-phenol reagent. J. biol. Chem. 192, 265.

MAGER, J. (1960). A TPNH-linked sulphite reductase and its relation to hydroxylamine reductase in Enterobacteriaceae. Biochim. biophys. Acta, 41, 553.

Marshail, R. O., Dishburger, H. J., MacVicar, R. \& Hallmark, G. D. (1953). Studies on the effect of aeration on nitrate reduction by Pseudomonas using $\mathrm{N}^{15}$. J. Bact. 64, 254.

Meiklejohn, J. (1940). Aerobic denitrification. Ann. appl. Biol. 27, 558.

OrnIsHI, T. \& MORI, T. (1960). Oxidative phosphorylation coupled with denitrification in intact cell systems. J. Biochem. (Tokyo), 48, 406.

Redfearn, E. R. \& Dixon, J. M. (1961). Spectrophotometric methods for the determination of succinic-dehydrogenase and succinic-oxidase activities in mitochondrial preparations. Biochem. J. 81, $19 \mathrm{P}$.

RIDer, B. F. \& Meldon, M. G. (1946). Colorimetric determination of nitrites. Industr. Engng Chem. (Anal.) 18, 96.

SACKS, L. E. \& BARKER, H. (1949). The influence of oxygen on nitrate and nitrite reduction. J. Bact. 58, 11.

SkERMAN, V. B. D., LACK, J. \& MILIIS, N. (1951). Influence of oxygen concentrations on the reduction of nitrate by Pseudomonas sp. in the growing culture. Aust. J. Sci. Res. B, 4, 511. 
Skerman, V. B. D. \& MacRae, I. C. (1957 $a)$. The influence of oxygen on the reduction of nitrate by adapted cells of Pseudomonas denitrificans. Canad. J. Microbiol. 3, 215.

Skerman, V. B. D. \& MacRaE, I. C. $(1957 b)$. The influence of oxygen availability on the degree of nitrate reduction by Pseudomonas denitrificans. Canad. J. Microbiol. 3, 505.

Skerman, V. B. D. \& MacRae, I. C. (1961). The influence of oxygen on the formation of nitratase in Pseudomonas denitrificans. Canad. J. Microbiol. 7, 169.

Takahashi, H., Taniguchi, S. \& Egami, F. (1956). Nitrate reduction in aerobic bacteria and that in $E$. coli coupled to phosphorylation. J. Biochem. (Tokyo), 43, 223.

Tanguchi, S., Sato, R. \& Egami, F. (1956). The enzymatic mechanisms of nitrate and nitrite metabolism in bacteria. In Inorganic Nitrogen Metabolism, p. 87. Ed. W. D. McElroy and B. Glass. Baltimore: The Johns Hopkins Press.

VERHoEven, W. (1956). Some remarks on nitrate metabolism in microorganisms. In Inorganic Nitrogen Metabolism, p. 61. Ed W. D. McElroy and B. Glass. Baltimore: The Johns Hopkins Press.

VoGEL, A. I. (1951). Quantitative Inorganic Analysis, 2nd ed., p. 249. London: Longmans, Green and Co. 